\title{
Phylogenetic analysis of gastric and enterohepatic Helicobacter species based on partial HSP60 gene sequences
}

\author{
Correspondence \\ Tiina Mikkonen \\ tiina.mikkonen@helsinki.fi
}

\author{
Tiina P. Mikkonen, Rauni I. Kärenlampi and Marja-Liisa Hänninen \\ Faculty of Veterinary Medicine, Department of Food and Environmental Hygiene, PO Box 57, \\ 00014 Helsinki University, Finland
}

\begin{abstract}
Analysis of $16 \mathrm{~S}$ rRNA gene sequences has been the method generally used to study the evolution and phylogeny of bacteria. Phylogenetic analysis of the 16S rRNA gene has shown the position of the genus Helicobacter in the $\varepsilon$-subclass of the Proteobacteria. Because $16 \mathrm{~S}$ rRNA-based phylogeny does not always correspond to the results of polyphasic taxonomy, and the related species cannot always be separated, new phylogenetic markers for Helicobacter species are needed. In this study, conserved partial (600 bp) 60 kDa heat-shock protein (HSP60) sequences were used to study the phylogeny of 37 strains of gastric and enterohepatic Helicobacter species, including type strains of 15 Helicobacter species with validly published names, reference strains of flexispira taxa and Helicobacter felis, Helicobacter bizzozeronii and Helicobacter salomonis and canine flexispira strains. The partial HSP60 gene sequence proved to be a useful phylogenetic marker for the genus Helicobacter, providing a means of differentiating all 15 Helicobacter species analysed. In the resulting phylogenetic tree, gastric Helicobacter species and enterohepatic species with flexispira morphology formed tight, separate clusters. In general, HSP60 sequence similarities between Helicobacter species were significantly lower than the corresponding 16S rRNA gene sequence similarities, indicating a better resolution for species identification. In addition, a specific PCR method for identifying $H$. salomonis was developed based on the partial HSP60 sequence.
\end{abstract}

\section{INTRODUCTION}

Helicobacter species have been isolated from the gastrointestinal tract of humans and several animal species, including cats, dogs, monkeys, sheep, pigs, rodents, birds, cheetahs and poultry (On, 1996, 2001; Solnick \& Schauer, 2001). At the time of writing (September 2003; http:// www.bacterio.cict.fr), there were 22 Helicobacter species with validly published names and two uncultured 'Candidatus' species (Dewhirst et al., 2000b). Several other Helicobacter taxa remain unnamed, because they have not been properly described according to the internationally accepted rules of nomenclature. Flexispiras constitute one of the unnamed groups of Helicobacter species, sharing spindleshaped cell morphology and periplasmic fibrils (Bryner et al., 1987). The group includes three species with validly published names, Helicobacter bilis (Fox et al., 1995),

Published online ahead of print on 21 November 2003 as DOI 10.1099/ijs.0.02839-0.

Abbreviation: HSP60, $60 \mathrm{kDa}$ heat-shock protein.

The GenBank/EMBL/DDBJ accession numbers for the Helicobacter HSP60 gene sequences determined in this study are AJ558199AJ558235.
Helicobacter trogontum (Mendes et al., 1996; Hänninen et al., 2003) and Helicobacter aurati (Patterson et al., 2000), plus several unnamed taxa (on the basis of analysis of $16 \mathrm{~S}$ rRNA gene sequences) (Dewhirst et al., 2000a).

Classification of helicobacters has been hampered by difficulties in growing them in vitro and by their inertness in traditionally used biochemical tests. Culture-independent genetic methods, such as $16 \mathrm{~S}$ rRNA gene sequence analysis, have therefore been applied to study the phylogeny of the genus as a basis for classification (Dewhirst et al., 2000a; Jalava et al., 1997; On, 2001). The results from 16S rRNA gene analyses are not always concordant with those of polyphasic taxonomy. For example, Helicobacter species flexispira 16S rRNA taxon 1, 4, 5 and 6 reference strains were widely scattered in the $16 \mathrm{~S}$ rRNA-based phylogenetic tree (Dewhirst et al., 2000a), but, according to the polyphasic taxonomy, they were all highly similar and shown to be members of $H$. trogontum (Hänninen et al., 2003). Similarly, Helicobacter cinaedi has a high degree of divergence in its 16S rRNA gene sequences (Vandamme et al., 2000). For most Helicobacter species, the intraspecific divergence of the 16S rRNA gene is not known.

Phylogenetic analysis of Helicobacter species based on urease 
$\alpha$-subunit amino acid sequences gave a result similar to that for 16S rRNA gene analysis, but phylogenetic analysis is restricted to urease-positive Helicobacter species (Gueneau \& Loiseaux-De Goër, 2002). The HSP60 (60 kDa heatshock protein) gene (GroEL, chaperonin), which encodes a $60 \mathrm{kDa}$ subunit of a complex assisting the threedimensional folding of bacterial proteins (Fink, 1999), has the potential to serve as a general phylogenetic marker because of its ubiquity and conservation in nature (Segal \& Ron, 1996). Studies on the suitability of a fragment from a conserved region of the HSP60 gene for phylogenetic analyses and speciation of the genera Staphylococcus and Macrococcus (Goh et al., 1996; Kwok \& Chow, 2003) and Bacteroides (Jian et al., 2001) have been published. These studies have shown that, despite the conserved nature of the HSP60 gene, interspecies variation in the DNA sequences is greater than that in the corresponding $16 \mathrm{~S}$ rRNA gene sequences, which may therefore provide better resolution for species classification.

The molecular methods used recently for identification of novel Helicobacter isolates include 16S and 23S rRNA PCRRFLP and species-specific PCR methods (Shen et al., 2000; Hurtado \& Owen, 1997). However, differentiation of the three closely related Helicobacter species Helicobacter felis, Helicobacter bizzozeronii and Helicobacter salomonis is not possible by these methods and requires a combination of whole-genome DNA-DNA hybridization and phenotypic analysis (Jalava et al., 1997).

In this study, our aim was to investigate the phylogeny of the genus Helicobacter, including some unnamed flexispira isolates, using $600 \mathrm{bp}$ partial HSP60 gene sequences. Our other goal was to develop a PCR method based on this gene fragment to differentiate the three closely related species $H$. felis, H. bizzozeronii and H. salomonis.

\section{METHODS}

Bacterial strains. Thirty-seven strains, including type and reference strains of various Helicobacter species and flexispira taxa, $H$. felis, H. bizzozeronii and H. salomonis strains and some Finnish canine flexispira strains, were used to study the phylogeny of partial HSP60 sequences (Table 1).

DNA isolation and PCR amplification. Bacteria were cultured on Brucella blood agar plates (Oxoid) containing selective antimicrobial agents (Hänninen et al., 1996) and grown microaerobically at $37^{\circ} \mathrm{C}$ for 2-3 days. Bacterial mass was collected from two or three plates and genomic DNA was isolated by the method of Pitcher et al. (1989) as described previously (Hänninen et al., 1996). The partial HSP60 gene sequence was amplified with the degenerate primers H60F (5'-GGNGAYGGNCANCANCANGCNCANGT-3') and H60R $\left(5^{\prime}\right.$-TCNCCRAANCCNGGNGCYTTNCANGC- $\left.3^{\prime}\right)$. The amplified region corresponds to nt 1345-1935 of the GroEL-like protein in Clostridium perfringens (Rusanganwa et al., 1992). The $50 \mu \mathrm{l} \mathrm{PCR}$ consisted of $1-3 \mu \mathrm{l}$ purified DNA, $5 \mathrm{nmol}$ each dNTP, $2 \cdot 5 \mathrm{U}$ Taq DNA polymerase (MBI Fermentas), $5 \mu \mathrm{l}$ buffer without $\mathrm{MgCl}_{2}$, $75 \mathrm{nmol} \mathrm{MgCl}_{2}$ and $100 \mathrm{pmol}$ each primer. The PCR thermal cycling conditions were as described previously (Jian et al., 2001).
Cloning and sequencing of PCR products. PCR products of the expected size were purified from $2 \%$ NuSieve GTG low-melting agarose gel (BioWhittaker Molecular Applications) with the Qiaquick gel extraction kit (Qiagen), cloned into pGEM-T Easy vector (Promega) and transformed to competent Escherichia coli JM109 cells (Promega). Ampicillin $\left(150 \mu \mathrm{g} \mathrm{ml}^{-1}\right)$ and blue/white selection were used to choose the transformants. Plasmids were isolated from several clones of each transformation with the Qiagen plasmid-purification Mini kit. To confirm the presence of the correct insert, plasmids were digested with EcoRI and restriction products were then separated in $1 \%$ agarose gel. Nucleotide sequencing of three cloned fragments was performed by automated cycle sequencing with Big Dye terminators (ABI 377XL; PE Applied Biosystems).

Sequence analysis. The partial HSP60 sequences determined in this study and those available in public databases [Helicobacter pylori CH-CTX1 (accession no. AF479030), H. pylori CCUG 17874 (X73840), H. pylori J99 (AE001439), H. pylori 26695 (AE000511), Campylobacter jejuni NCTC 11168 (AY044099) and Campylobacter coli NCTC 11353 (AY044098)] were analysed with BIONUMERICS software (version 3.0; Applied Maths). After pairwise and multiple alignments, a phylogenetic tree was constructed by using the neighbour-joining method (Saitou \& Nei, 1987) and the JukesCantor coefficient (Jukes \& Cantor, 1969). The topology of the tree was evaluated by performing 1000 trials of bootstrap analysis. The DNA sequences were translated to the corresponding protein sequences with the TRANSEQ program (EMBOSS; European Molecular Biology Open Software Suite). The resulting protein sequences were aligned and a neighbour-joining tree calculated with CLUSTAL W (Thompson et al., 1994). The phylogenetic tree based on the protein sequences was drawn using TREEVIEW version 1.6.6 (http:// taxonomy.zoology.gla.ac.uk/rod/rod.html).

Species-specific PCR for differentiating $\boldsymbol{H}$. felis, $\boldsymbol{H}$. bizzozeronii and $\boldsymbol{H}$. salomonis. Specific primers for amplifying a partial HSP60 sequence from $H$. felis, $H$. bizzozeronii or $H$. salomonis were designed with the PRIMER3 program and tested against the strains of three species by using the PRIMERSEARCH program (EMBOSS). The primer pairs were tested in the laboratory with five representative strains from each of the three species. The PCR cycling program for the specific primers was the same as that for the degenerate H60F and H60R primers except that, after optimization experiments, the annealing temperature was raised to $66^{\circ} \mathrm{C}$.

\section{RESULTS AND DISCUSSION}

\section{Phylogenetic analysis of DNA sequences}

A phylogenetic tree based on the partial HSP60 sequences was constructed (Fig. 1). The topology of the neighbourjoining tree was basically similar to those of trees based on 16S rRNA or urease $\alpha$-subunit amino acid sequences (Dewhirst et al., 2000a; Gueneau \& Loiseaux-De Goër, 2002), with gastric species forming a tight cluster (cluster 1) and enterohepatic species a more diverse one (cluster 2). Interspecies sequence similarity values ranged from $61 \cdot 4$ to $94.2 \%$ (mean $72 \%$ ), showing much higher variation than that in $16 \mathrm{~S}$ rRNA gene sequences, where the similarities between Helicobacter species ranged from $88 \cdot 7$ to 99.2 \% (Jalava et al., 1997; Dewhirst et al., 2000a). In the genus Bacteroides, interspecies similarity of the respective sequences ranged from 73 to $96 \%$ (mean $85 \%$ ) (Jian et al., 2001). These results support the idea that the HSP60 gene 
Table 1. Helicobacter strains used in this study

\begin{tabular}{|c|c|c|}
\hline Taxon & Strain/reference & Source \\
\hline H. acinonychis & 90-1908 (=ATCC 51104) & Cheetah gastric mucosa \\
\hline \multirow[t]{5}{*}{ H. bizzozeronii } & Storkis $^{\mathrm{T}}\left(=\right.$ CCUG $\left.35545^{\mathrm{T}}\right)$ & Canine gastric mucosa \\
\hline & Emo (Jalava et al., 1998) & Canine gastric mucosa \\
\hline & 10 (Jalava et al., 1998) & Canine gastric mucosa \\
\hline & Yrjälä (Jalava et al., 1998) & Canine gastric mucosa \\
\hline & R-53 (Jalava et al., 2001) & Human gastric mucosa \\
\hline H. canis & NCTC $12739^{\mathrm{T}}$ & Canine faeces \\
\hline H. cinaedi & CCUG $18818^{\mathrm{T}}$ & Human faeces \\
\hline H. cholecystus & CCUG 38167 & Syrian hamster gall-bladder \\
\hline \multirow[t]{4}{*}{ H. felis } & CS1 (=ATCC 49179) & Feline gastric mucosa \\
\hline & DS3 (Paster et al., 1991) & Canine gastric mucosa \\
\hline & Kukka (Jalava et al., 1998) & Canine gastric mucosa \\
\hline & Lopki13 (Jalava et al., 1998) & Feline gastric mucosa \\
\hline H. hepaticus & CCUG $33637^{\mathrm{T}}$ & Mouse liver \\
\hline H. muridarum & CCUG $29262^{\mathrm{T}}$ & Rat ileum \\
\hline H. mustelae & CCUG $25715^{\mathrm{T}}$ & Ferret gastric mucosa \\
\hline H. pametensis & CCUG 29253 & Tern faeces \\
\hline H. pullorum & NCTC 12826 & Human faeces \\
\hline \multirow[t]{2}{*}{ H. pylori } & Tx30a (=ATCC 51932) & Human gastric mucosa \\
\hline & 7546 & Human gastric mucosa \\
\hline \multirow[t]{4}{*}{ H. salomonis } & Inkinen $^{\mathrm{T}}\left(=\mathrm{CCUG} 37845^{\mathrm{T}}\right)$ & Canine gastric mucosa \\
\hline & 06A (=CCUG 37848) & Canine gastric mucosa \\
\hline & HS100 & Canine gastric mucosa \\
\hline & Ko. K. III (Jalava et al., 1998) & Canine gastric mucosa \\
\hline H. trogontum & HU H95S (Hänninen et al., 2003) & Pig faeces \\
\hline H. trogontum & 86-13625 (=ATCC 43968) & Pig \\
\hline Helicobacter sp., taxon 2 & 86-2279 (=ATCC 49314) & Sheep \\
\hline Helicobacter sp., taxon 3 & 88-2491（=ATCC 49320） & Pig stomach; aborted fetus \\
\hline H. trogontum & 86-1775 (=ATCC 49310) & Sheep \\
\hline H. trogontum & 84-3345 (=ATCC 43966) & Aborted sheep fetus \\
\hline H. trogontum & ATCC $700114^{\mathrm{T}}$ & Rat gut \\
\hline Helicobacter sp., taxon 8 & CCUG 23435 & Human faeces \\
\hline H. bilis & ATCC $51630^{\mathrm{T}}$ & Mouse faeces \\
\hline \multirow[t]{4}{*}{ Canine 'flexispira' } & FL56 & Canine gastric mucosa \\
\hline & KO214 & Canine gastric mucosa \\
\hline & KO220 & Canine gastric mucosa \\
\hline & KO534B & Canine gastric mucosa \\
\hline
\end{tabular}

would give better resolution for species identification than the 16S rRNA gene. The high similarity of the overall structures of the phylogenetic trees based on 16S rRNA, urease $\alpha$-subunit and partial HSP60 sequences reveals the early division of the species into gastric and enterohepatic lineages. The enterohepatic species Helicobacter canis, Helicobacter cholecystus, Helicobacter pametensis, H. cinaedi, Helicobacter hepaticus, Helicobacter pullorum and Helicobacter mustelae remained outside these two clusters. These species formed no distinct or stable cluster(s) in the tree (Fig. 1).

The topology of the gastric cluster (cluster 1) was also similar to the one in the 16S rRNA analysis (Dewhirst et al., 2000a; Gueneau \& Loiseaux-De Goër, 2002) and it was further subdivided, with high bootstrap support, into two subclusters (subclusters 1 and 2). Sequence similarities between species in cluster 1 ranged from 75.8 to $94 \cdot 3 \%$ (mean $83 \cdot 2 \%$ ). Subcluster 1 included the six H. pylori strains and Helicobacter acinonychis, and these two species were clearly separated from each other (with a sequence similarity in the range $93 \cdot 8-95 \cdot 0 \%$ ). HSP60 DNA sequence similarities between the six $H$. pylori strains ranged from 96.6 to $98 \cdot 3 \%$ (mean $97 \cdot 3 \%$ ), demonstrating that the intraspecies similarity within subcluster 1 is higher than the interspecies similarity. Both comparison of several $16 \mathrm{~S}$ rRNA gene sequences (Eckloff et al., 1994) and the use of other sequence-based genotyping methods (Maggi Solcà et al., 2001) have revealed high diversity for H. pylori. Subcluster 2 included gastric species $H$. salomonis, $H$. bizzozeronii and $H$. felis. H. salomonis strains were separated from $H$. felis and $H$. bizzozeronii with strong bootstrap 


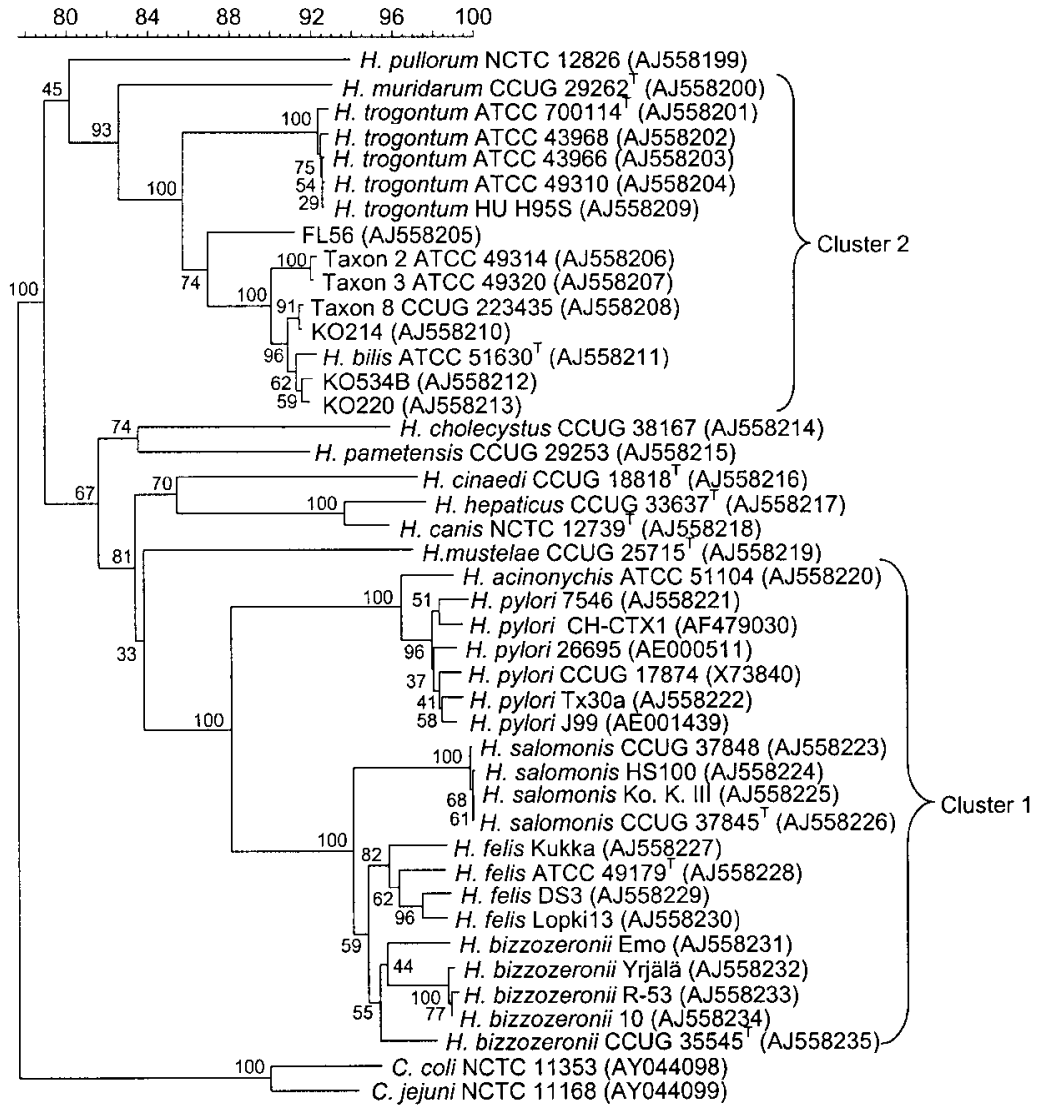

Fig. 1. Phylogenetic tree based on partial HSP60 DNA sequences. The tree was constructed by use of the neighbour-joining method and rooted with sequences from Campylobacter coli and Campylobacter jejuni. Numbers at branch-points represent percentage bootstrap support calculated from 1000 trees. The scale bar represents the sequence divergence of sequences. support. Interspecies similarity within subcluster 2 was in the range $88 \cdot 1-93 \cdot 2 \%$, revealing higher diversity than that within subcluster 1 . Interstrain similarity was high in H. salomonis (mean 99.7\%). H. felis and H. bizzozeronii had more divergent sequences, respectively showing approximately $95 \cdot 1 \%$ (range $93 \cdot 8-97 \cdot 4 \%$ ) and $95 \cdot 4 \%$ (range $93 \cdot 2-99 \cdot 6 \%$ ) interstrain similarity. The $16 \mathrm{~S}$ rRNA gene sequences of two $H$. salomonis strains differed by $1.7 \%$ (Jalava et al., 1997), indicating higher variability than for HSP60 sequences. The human $H$. bizzozeronii strain R-53, previously known as 'Helicobacter heilmannii' type 1, clearly clustered with canine $H$. bizzozeronii strains, thus confirming the results based on the polyphasic taxonomic studies of the strain (Jalava et al., 2001).

Cluster 2 included all enterohepatic strains with flexispira morphology: $H$. bilis and Helicobacter muridarum type strains, five $H$. trogontum strains, reference strains of Helicobacter sp. flexispira taxa 2, 3 and 8 and four Finnish canine flexispira isolates (KO534B, KO220, KO214 and F56). H. trogontum strains grouped tightly together and were separate from the other species. The sequence similarity between the two species $H$. bilis and $H$. trogontum ranged from $88 \cdot 4$ to $88.9 \%$ (mean $88.6 \%$ ). Three of the canine isolates $(\mathrm{KO} 534 \mathrm{~B}, \mathrm{KO} 220$ and $\mathrm{KO} 214)$ clustered tightly (mean $98.4 \%$ similarity) with $H$. bilis and the taxon 8 reference strain. $H$. bilis has been isolated from several animal species, including mouse, dog, hamster, gerbil and rat (Fox et al., 1995; Solnick \& Schauer, 2001). Our present results, as well as the results of cytolethal distending toxin gene sequencing (Kostia et al., 2003), suggest a close relationship between $H$. bilis and canine flexispiras, but further studies are needed to confirm the taxonomy of the latter. Reference strains of taxa 2 and 3 were located in their own branch, as was the canine isolate FL56.

In the $16 \mathrm{~S}$ rRNA analysis, $H$. trogontum strains were widely dispersed among enterohepatic Helicobacter species (Dewhirst et al., 2000a; Hänninen et al., 2003). For example, strains ATCC 43968 and ATCC 49310 differed by $4 \cdot 4 \%$ in their 16S rRNA gene sequences (Hänninen et al., 2003) but showed only $0.6 \%$ difference in the partial HSP60 sequences. Between strains ATCC 43968 and ATCC 43966, the corresponding differences were respectively $4.7 \%$ (Dewhirst et al., 2000a; Hänninen et al., 2003) and 0.6\%. These results show that, in the case of $H$. trogontum, HSP60 gene phylogeny predicts taxonomy much better than does the $16 \mathrm{~S}$ rRNA gene. In general, our studies revealed that the evolution of the 16S rRNA and HSP60 genes is not similar, 16S rRNA being more often a target of genetic changes.

Although the enterohepatic species $H$. pullorum, H. cholecystus, $H$. pametensis, $H$. cinaedi, H. hepaticus and $H$. canis did not cluster together, they were more similar to each other (mean interspecies similarity $75 \cdot 4 \%$ ) and other 
enterohepatic species in cluster 2 than to any species in cluster 1 (mean interspecies similarity 69.3\%). All these species, except $H$. hepaticus, are urease-negative. This characteristic could suggest the intestine as the primary niche for colonization, because all gastric Helicobacter species are urease-positive (Solnick \& Schauer, 2001). The HSP60 sequence of $H$. mustelae, a gastric species colonizing the stomach of the ferret (Paster et al., 1991; Solnick \& Schauer, 2001), was most closely related to that of $H$. canis $(75 \cdot 3 \%$ similarity) and its phylogenetic position was unstable, since only a very low bootstrap value $(33 \%)$ supported its present position in the HSP60 phylogenetic tree. As a result of analyses of the urease $\alpha$-subunit and 16S rRNA genes of $H$. mustelae, it is suggested that it is phylogenetically more closely related to enterohepatic than to gastric helicobacters (Gueneau \& Loiseaux-De Goër, 2002). All evidence from its biology indicates, however, that it is a Helicobacter species that primarily colonizes the gastric region (Fox et al., 1990).

\section{Phylogenetic analysis of protein sequences}

The same two major clusters (cluster 1 and cluster 2) seen in the DNA sequence tree were formed in the phylogenetic tree constructed from the deduced partial HSP60 protein sequences (180 aa) (Fig. 2). Within cluster 1, the amino acid sequence similarity between species ranged from $94 \cdot 4$ to $99.9 \%$ (mean $96.4 \%$ ). In cluster 2 , the overall similarity between protein sequences was $99 \cdot 4 \%$. Because of the higher similarity between protein sequences than between DNA sequences, none of the species could be differentiated from each other. The high similarity values for HSP60 protein sequences indicate that most of the differences were due to silent mutations. The highest similarity between species $(100 \%)$ was between $H$. trogontum, $H$. bilis and taxon 8 reference strain (cluster A), while the lowest similarity $(84 \cdot 4 \%)$ was between $H$. cinaedi and $H$. pullorum. The partial HSP60 protein sequences for the species $H$. pylori, $H$. trogontum and $H$. salomonis were all identical. Within H. bizzozeronii, two of the strains, Emo and R-53, differed from the other three strains by one amino acid, and from each other by two amino acids. $H$. felis strain Kukka differed from the three other strains of the same species by one amino acid.

\section{Specific PCR for differentiating $\boldsymbol{H}$. felis, $H$. bizzozeronii and $H$. salomonis}

$H$. bizzozeronii, $H$. felis and $H$. salomonis are closely related, and phenotypic tests do not differentiate these three species; thus, new genotypic tests are required (Jalava et al., 1997). The primer pair designed for $H$. salomonis (HSALF: 5'-CATTTTCAAAGAGGGCTTGC-3'; HSALR: $5^{\prime}$-GCACACCCCTCAGTTTGTTT- $3^{\prime}$ ) was the only one that showed a species-specific PCR product when tested in the laboratory, producing the $537 \mathrm{bp}$ amplicon only for H. salomonis strains. The present PCR method is a useful tool for species-specific identification of $H$. salomonis. The

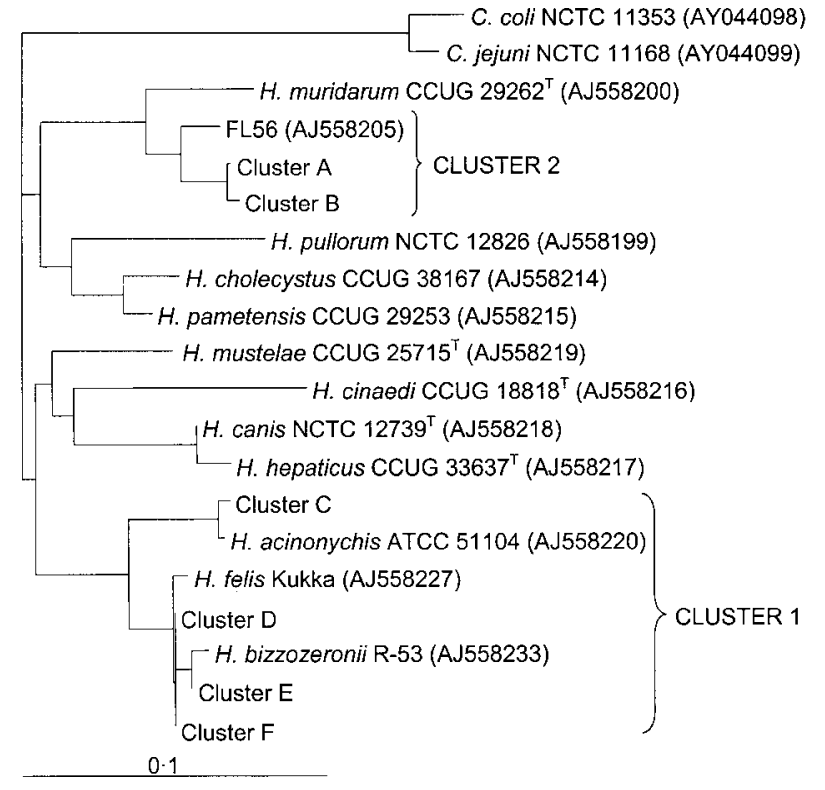

Fig. 2. Phylogenetic tree based on deduced partial HSP6O protein sequences. Identical sequences are represented as clusters $A-F$ and include the following strains: $A, H$. bilis ATCC $51630^{\top}, \mathrm{KO} 534 \mathrm{~B}, \mathrm{KO} 220, \mathrm{KO} 214, H$. trogontum HU H95S, taxon 8 CCUG 223435, $H$. trogontum ATCC $700114^{\top}$, $H$. trogontum ATCC 43966, $H$. trogontum ATCC 43968, $H$. trogontum ATCC 49310; B, taxon 2 ATCC 49314, taxon 3 ATCC 49320; C, H. pylori 7546, H. pylori CH-CTX1, H. pylori 26695, H. pylori CCUG 17874, H. pylori Tx30a, H. pylori J99; D, H. salomonis 06A, H. felis Lopki13, H. felis DS3, H. felis ATCC $49179^{\top}, H$. bizzozeronii Emo; E, $H$. bizzozeronii CCUG $35545^{\top}, H$. bizzozeronii $10, H$. bizzozeronii Yrjälä; F: $H$. salomonis CCUG $37845^{\top}, H$. salomonis Ko. K. III, H. salomonis HS100. The tree was constructed by using the neighbourjoining method and was rooted with sequences from Campylobacter coli and Campylobacter jejuni. The scale bar represents $0 \cdot 1$ substitutions per site.

intraspecies divergence of the two other species was high and no species-specific primers were detected.

\section{Conclusions}

In conclusion, we have shown that the 600 bp HSP60 gene sequence is a suitable phylogenetic marker for the genus Helicobacter. The degenerate primers used amplify DNA of several bacterial genera, offering the possibility of extending phylogenetic analysis of diverse bacterial species. New insight into the phylogeny of Helicobacter sp. flexispira taxa was achieved, but further studies are needed to describe the taxonomy of taxa 2 and 3 and taxon $8, H$. bilis and canine flexispiras.

The rather high level of interspecies sequence divergence in the genus Helicobacter suggests that development of species-specific PCR or DNA-DNA hybridization tests is also possible for species other than $H$. salomonis. 


\section{ACKNOWLEDGEMENTS}

This study was partially supported by grants from Helsinki University Funds and The Finnish Academy.

\section{REFERENCES}

Bryner, J. H., Richie, A. E., Pollet, L., Kirkbridge, C. A. \& Collins, J. E. (1987). Experimental infection and abortion of pregnant guinea pigs with a unique spirillum-like bacterium isolated from aborted ovine fetuses. Am J Vet Res 48, 91-95.

Dewhirst, F. E., Fox, J. G., Mendes, E. N., Paster, B. J., Gates, C. E., Kirkbride, C. A. \& Eaton, K. A. (2000a). 'Flexispira rappini' strains represent at least 10 Helicobacter taxa. Int J Syst Evol Microbiol 50, 1781-1787.

Dewhirst, F. E., Fox, J. G. \& On, S. L. W. (2000b). Recommended minimal standards for describing new species of the genus Helicobacter. Int J Syst Evol Microbiol 50, 2231-2237.

Eckloff, B. W., Podzorski, R. P., Kline, B. C. \& Cockerill, F. R., III (1994). A comparison of $16 S$ ribosomal DNA sequences from five isolates of Helicobacter pylori. Int J Syst Bacteriol 44, 320-323.

Fink, A. L. (1999). Chaperone-mediated protein folding. Physiol Rev 79, 425-449.

Fox, J. G., Correa, P., Taylor, N. S., Lee, A., Otto, G., Murphy, J. C. \& Rose, R. (1990). Helicobacter mustelae-associated gastritis in ferrets. An animal model of Helicobacter pylori gastritis in humans. Gastroenterology 99, 352-361.

Fox, J. G., Yan, L. L., Dewhirst, F. E., Paster, B. J., Shames, B., Murphy, J. C., Hayward, A., Belcher, J. C. \& Mendes, E. N. (1995). Helicobacter bilis sp. nov., a novel Helicobacter species isolated from bile, livers, and intestines of aged, inbred mice. J Clin Microbiol 33, 445-454.

Goh, S. H., Potter, S., Wood, J. O., Hemmingsen, S. M., Reynolds, R. P. \& Chow, A. W. (1996). HSP60 gene sequences as universal targets for microbial species identification: studies with coagulasenegative staphylococci. J Clin Microbiol 34, 818-823.

Gueneau, P. \& Loiseaux-De Goër, S. (2002). Helicobacter: molecular phylogeny and the origin of gastric colonization in the genus. Infect Genet Evol 1, 215-223.

Hänninen, M.-L., Happonen, I., Saari, S. \& Jalava, K. (1996). Culture and characteristics of Helicobacter bizzozeronii, a new canine gastric Helicobacter sp. Int J Syst Bacteriol 46, 160-166.

Hänninen, M.-L., Utriainen, M., Happonen, I. \& Dewhirst, F. E. (2003). Helicobacter sp. flexispira 16S rDNA taxa 1, 4 and 5 and Finnish porcine Helicobacter isolates are members of the species Helicobacter trogontum (taxon 6). Int J Syst Evol Microbiol 53, 425-433.

Hurtado, A. \& Owen, R. J. (1997). A rapid identification scheme for Helicobacter pylori and other species of Helicobacter based on 23S rRNA gene polymorphism. Syst Appl Microbiol 20, 222-231.

Jalava, K., Kaartinen, M., Utriainen, M., Happonen, I. \& Hänninen, M.-L. (1997). Helicobacter salomonis sp. nov., a canine gastric Helicobacter sp. related to Helicobacter felis and Helicobacter bizzozeronii. Int J Syst Bacteriol 47, 975-982.

Jalava, K., On, S. L. W., Vandamme, P. A. R., Happonen, I., Sukura, A. \& Hänninen, M.-L. (1998). Isolation and identification of Helicobacter spp. from canine and feline gastric mucosa. Appl Environ Microbiol 64, 3998-4006.

Jalava, K., On, S., Harrington, C. S., Andersen, L., Hänninen, M.-L. \& Vandamme, P. (2001). A cultured strain of "Helicobacter heilmannii," a human gastric pathogen identified as H. bizzozeronii: evidence for zoonotic potential of Helicobacter. Emerg Infect Dis 7, 1036-1038.

Jian, W., Zhu, L. \& Dong, X. (2001). New approach to phylogenetic analysis of the genus Bifidobacterium based on partial HSP60 gene sequences. Int J Syst Evol Microbiol 51, 1633-1638.

Jukes, T. H. \& Cantor, C. R. (1969). Evolution of protein molecules. In Mammalian Protein Metabolism, pp. 21-132. Edited by H. N. Munro. New York: Academic Press.

Kostia, S., Veijalainen, P., Hirvi, U. \& Hänninen, M.-L. (2003). Cytolethal distending toxin $\mathrm{B}$ gene $(c d t B)$ homologues in taxa 2, 3 and 8 and in six canine isolates of Helicobacter sp. flexispira. $J$ Med Microbiol 52, 103-108.

Kwok, A. Y. C. \& Chow, A. W. (2003). Phylogenetic study of Staphylococcus and Macrococcus species based on partial hsp60 gene sequences. Int J Syst Evol Microbiol 53, 87-92.

Maggi Solcà, N., Bernasconi, M. V., Valsangiacomo, C., Van Doorn, L.-J. \& Piffaretti, J.-C. (2001). Population genetics of Helicobacter pylori in the southern part of Switzerland analysed by sequencing of four housekeeping genes ( $a t p D, g \ln A, \operatorname{sco} B$ and $\operatorname{rec} A$ ), and by $v a c A$, cagA, iceA and IS605 genotyping. Microbiology 147, 1693-1707.

Mendes, E. N., Queiroz, D. M. M., Dewhirst, F. E., Paster, B. J., Moura, S. B. \& Fox, J. G. (1996). Helicobacter trogontum sp. nov., isolated from the rat intestine. Int J Syst Bacteriol 46, 916-921.

On, S. L. W. (1996). Identification methods for campylobacters, helicobacters, and related organisms. Clin Microbiol Rev 9, 405-422.

On, S. L. W. (2001). Taxonomy of Campylobacter, Arcobacter, Helicobacter and related bacteria: current status, future prospects and immediate concerns. J Appl Microbiol 90, 1S-15S.

Paster, B. J., Lee, A., Fox, J. G., Dewhirst, F. E., Tordoff, L. A., Fraser, G. J., O'Rourke, J. L., Taylor, N. S. \& Ferrero, R. (1991). Phylogeny of Helicobacter felis sp. nov., Helicobacter mustelae, and related bacteria. Int J Syst Bacteriol 41, 31-38.

Patterson, M. M., Schrenzel, M. D., Feng, Y., Xu, S., Dewhirst, F. E., Paster, B. J., Thibodeau, S. A., Versalovic, J. \& Fox, J. G. (2000). Helicobacter aurati sp. nov., a urease-positive Helicobacter species cultured from gastrointestinal tissues of Syrian hamsters. J Clin Microbiol 38, 3722-3728.

Pitcher, D. G., Saunders, N. A. \& Owen, R. J. (1989). Rapid extraction of bacterial genomic DNA with guanidium thiocyanate. Lett Appl Microbiol 8, 151-156.

Rusanganwa, E., Singh, B. \& Gupta, R. S. (1992). Cloning of HSP60 (GroEL) operon from Clostridium perfringens using a polymerase chain reaction based approach. Biochim Biophys Acta 1130, 90-94.

Saitou, N. \& Nei, M. (1987). The neighbor-joining method: a new method for reconstructing phylogenetic trees. Mol Biol Evol 4, 406-425.

Segal, G. \& Ron, E. Z. (1996). Regulation and organization of the groE and dnaK operons in Eubacteria. FEMS Microbiol Lett 138, 1-10.

Shen, Z., Feng, Y. \& Fox, J. G. (2000). Identification of enterohepatic Helicobacter species by restriction fragment-length polymorphism analysis of the 16S rRNA gene. Helicobacter 5, 121-128.

Solnick, J. V. \& Schauer, D. B. (2001). Emergence of diverse Helicobacter species in the pathogenesis of gastric and enterohepatic diseases. Clin Microbiol Rev 14, 59-97.

Thompson, J. D., Higgins, D. G. \& Gibson, T. J. (1994). CLUSTAL W: improving the sensitivity of progressive multiple sequence alignment through sequence weighting, position-specific gap penalties and weight matrix choice. Nucleic Acids Res 22, 4673-4680.

Vandamme, P., Harrington, C. S., Jalava, K. \& On, S. L. (2000). Misidentifying helicobacters: the Helicobacter cinaedi example. J Clin Microbiol 38, 2261-2266. 